\title{
NEW TAXA OF SOLENOSTOMA AND PLECTOCOLEA AND OTHER TAXONOMIC NOVELTIES BASED ON STUDY OF COLLECTIONS IN THE NEW YORK BOTANICAL GARDEN HERBARIUM
}

\author{
VADIM A. BAKALIN
}

\begin{abstract}
Six new taxa are described based on study of Jungermannia s.l. collections in herbarium NY. Solenostoma costaricanum Bakalin, sp. nov. is related to S. crassulum (Nees \& Mont.) Steph., from which it differs in plant size, the presence of ventral stolons, perianth shape, spore and elater size. Plectocolea subbalfourii Bakalin, sp. nov. is related to Solenostoma (Plectocolea) balfourii (Ván̆a) Váňa, Hentschel \& J. Heinrichs, from which it differs in rhizoid features and size of perigynium and midleaf cells. Solenostoma rubrum var. underwoodii Bakalin, var. nov., based on Nardia macounii Underwood, nom. nud., differs from var. rubrum in coloration and leaf structure features. Plectocolea yunnanensis Bakalin, sp. nov., belonging to the 'Plectocolea truncata' group, differs from related species in leaf structure and rhizoid features. Solenostoma gracillimum subsp. camiguinense Bakalin, subsp. nov. differs from the typical variety in perianth and leaf structure features. Solenostoma inundatum var. grandirete Bakalin, var. nov. differs from the typical variety in leaf structure. Additionally, it was found that the type specimen of Plectocolea micrantha Mitt. is paroicous, not dioicous. Critical study of type specimens of Jungermannia marcescens Mitt. and J. sanguinolentha Griff. showed that these taxa are not conspecific, and the new combination Solenostoma marcescens (Mitt.) Bakalin, comb. nov. is proposed.
\end{abstract}

Key words: Jungermannia s.1., Solenostoma, Plectocolea, taxonomy, Solenostomataceae.

Vadim A. Bakalin, Botanical Garden - Institute, Far Eastern Branch of the Russian Academy of Sciences, Vladivostok 690024, Russia, and Institute of Biology and Soil Science, Institute Far Eastern Branch of the Russian Academy of Sciences; Vladivostok 690022, Russia; e-mail: v_bak@list.ru

In the course of my study of Jungermannia s.l. specimens in the Herbarium of the New York Botanical Garden (NY) I found some previously undescribed taxa and other taxonomic novelties which are presented below.

\section{Solenostoma costaricanum Bakalin, sp. nov.}

Fig. 1

Plants $2.2-4.4 \times(0.22-) 0.30-0.88 \mathrm{~mm}$, mostly brownish, but with apex commonly red to brownred and purple (red coloration more obvious in female shoots with fertilized archegonia); ascending, delicate. Stem 110-132 $\mu \mathrm{m}$ in diameter, brownish with ventral side more deeply colored, rarely branched, with branches of three types: ventral scale-leaved stolons, turning into ordinary branch, lateral intercalary, lateral and ventral subfloral innovations. Rhizoids sparse to common, colorless to lightly brownish, not forming fascicles, originated in ventral side of stem and lower half of perianth (ventral and lateral sides). Leaves concave to concave-flattened, subtransversely inserted $\left(65-80^{\circ}\right.$ with axis), shortly ( $1 / 4-1 / 3$ of stem width) decurrent dorsally, ventrally transversely inserted, not or barely decurrent, transversely elliptic to reniform, 374-616 $\times 520-770 \mu \mathrm{m}$, distant in sterile and contiguous in fertile shoots. Leaf cells in midleaf shortly oblong, $25.2-39.6 \times 21.0-27.3$ $\mu \mathrm{m}$, thin-walled, walls colorless, trigones moderate to small, concave; along margin 21.0-33.6 $\mu \mathrm{m}$, thin-walled, with thin to slightly thickened external wall, trigones moderate, concave; cells in basal part similar to those in middle, but longer as up to $61 \mu \mathrm{m}$ in length, cuticle distinctly papillose to papillose striolate. Dioicous. Androecia intercalary, in 3-4 pairs of bracts, 1-3-androus, stalk biseriate, ca $17 \mu \mathrm{m}$ long. Male bracts strongly concave with recurved margin above. Perianth terminal, with 1-3 subfloral innovations (if 3: 2 lateral, 1 ventral), exerted for $3 / 4$ of its length, mostly 3 -plicate in 


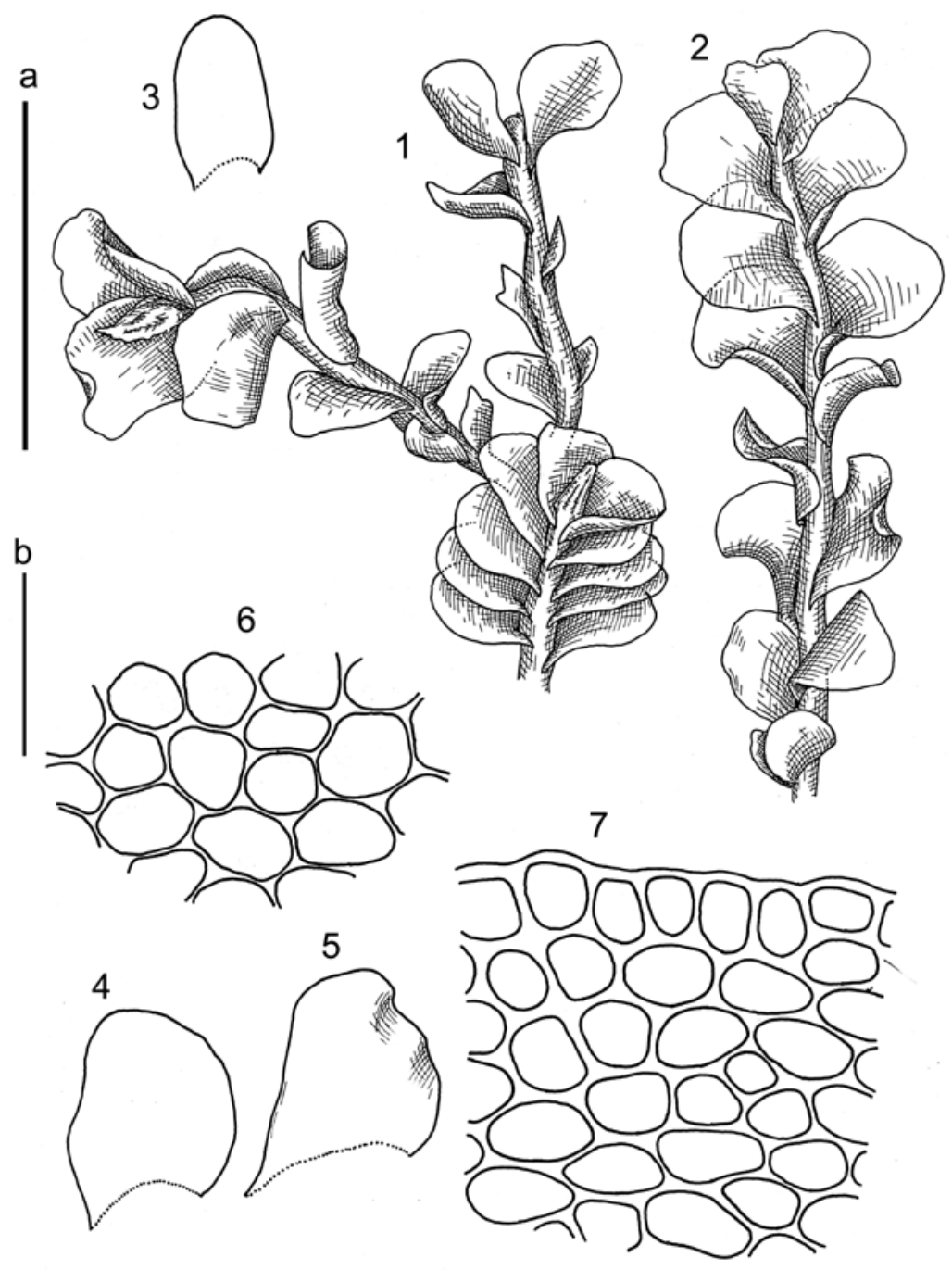

Fig. 1. Solenostoma costaricanum Bakalin, sp. nov. 1 - female plant; 2 - sterile plant; 3-5 - leaves; 6 - midleaf cells; 7 - cells along leaf margin. Scale bars: $\mathrm{a}-1 \mathrm{~mm}$ for $1-5 ; \mathrm{b}-50 \mu \mathrm{m}$ for $6 \&$ 7. All from holotype (NY 636521).

upper $1 / 3-1 / 4$, gradually or suddenly contracted to the commonly very weakly beaked or not beaked mouth, obpyriform to clavate, rhizogenous in lower half; mouth dentate, teeth 1-celled, cells ca 31.5-42.0 × 14.7-21.0 $\mu \mathrm{m}$ with moderately thickened walls; cells in upper part of perianth $21.0-33.6 \times 14.7-21.0 \mu \mathrm{m}$, shortly oblong to isodiametric, thin-walled, trigones moderate to large, convex, walls pink; cells in middle part of perianth $27.3-42.0 \times 21.0-23.1 \mu \mathrm{m}$, oblong, thin- walled, trigones moderate, convex, walls pinkish, cuticle papillose; cells in lower part of perianth similar to those in middle, but walls colorless and cells longer, up to $48.3 \mu \mathrm{m}$ long, cuticle striolate; perianth unistratose to base. Perigynium virtually absent. Female bracts concave-canaliculate, sheathing perianth in base and obliquely spreading above. Elaters bispiral, ca $84 \times 5 \mu \mathrm{m}$, with long ( $c a$ $20 \mu \mathrm{m})$ homogenous ends. Spores brown-purple, finely papillose, $16.8-21.0 \mu \mathrm{m}$ in diameter. 
Holotype. COSTA RICA: Alajuela, Calera de San Ramon, 29 Jan 1934, A. M. Brenes 19033 (NY 636521).

This species is rather closely related to Solenostoma crassulum (Nees \& Mont.) Steph., from which it differs by its $(i)$ smaller size of plants, $2.2-4.4$ $\times(0.22-) 0.3-0.88 \mathrm{~mm}$ (vs. 5-20 × 0.5-1.8 mm); (ii) sporadic presence of ventral scale-leaved stolons (not known in $S$. crassula); (iii) oblong and narrower (narrower than $23 \mu \mathrm{m}$ ) cells in perianth middle (vs. isodiametric, 30-35 $\mu \mathrm{m}$ ); (iv) larger spores (up to $21 \mu \mathrm{m}$ in diameter, vs. 16-17 $\mu \mathrm{m}$ in diameter), and ( $v$ ) shorter elaters ( $c a$ 80-90 vs. 120-150 $\mu \mathrm{m})$. The specimen was identified as Jungermannia (Solenostoma) amoena Lindenb. $\&$ Gottsche, from which it differs by having androecia in 3-4 pairs (vs. 6-12), sometimes a shortly beaked perianth mouth (vs. rounded, not beaked), flaccid shoots (vs. rigid) and the absence of a perigynium (vs. common presence).

\section{Plectocolea subbalfourii Bakalin, sp. nov.}

Fig. 2

Plants ascending to erect, by appearance similar to Plectocolea virgata Mitt., greenish yellowish to greenish brownish and brown, 5-10 $\times(0.66-) 1.54-2.64 \mathrm{~mm}$, small (like innovations) branches starting from $0.60 \mathrm{~mm}$ in width sometimes present. Stem 198-264 $\mu \mathrm{m}$ in diameter, greenish brownish to brown, commonly more deeply colored than leaves, branching ventral, branches appeared as geotropic leafless stolons, turning into normal branches or dying. Rhizoids numerous, colorless to brownish, purplish brown and reddish brown, erect spreading, or more frequently, decurrent down the stem, rarely forming unclear fascicles. Leaves mostly erect spreading to obliquely spreading, concave-canaliculate to almost flattened, in upper part of perianthous shoots loosely sheathing the stem near leaf base, shortly (up to 1/4 of stem width) decurrent dorsally, and transversely inserted and not decurrent ventrally, laterally subtransversely inserted, $\mathrm{ca}$ 65-80 $0^{\circ}$ with stem axis; obliquely elliptic to ovate, $1122-1430 \times$ 990-1276 $\mu \mathrm{m}(0.9: 1)$. Leaf cells in midleaf isodiametric to shortly oblong, $52.5-69.3 \times 42-56.7 \mu \mathrm{m}$, thin-walled, trigones moderate, convex, cuticle smooth; along margin 31.5-42 $\mu \mathrm{m}$, trigones moderate, convex, external wall strongly thickened, cuticle loosely verrucose; basal cells 60.9-94.5 $\times 31.5-42.0 \mu \mathrm{m}$, thin-walled, trigones moderate, convex, cuticle smooth. Dioicous. Perianth terminal, innovations rare, in shape conical, pluriplicate, with 3-5 main plicae, not rhizogenous, mouth not beaked, exerted from bracts for $1 / 4-1 / 2$ of its length; mouth crenulate due to protrudent elongate $(42-63 \times 14.7-31.5 \mu \mathrm{m})$ thick- to (rarely) thin-walled cells; cells in upper part of perianth oblong, 52.5-73.5 × 18.9-21.0 $\mu \mathrm{m}$, thin-walled, with small concave trigones, cuticle smooth; cells in middle part of perianth similar to upper; cells in lower part of perianth elongate, mostly long rectangular, 94.5-147.0 $\times 21-35 \mu \mathrm{m}$, thin-walled, cuticle smooth, trigones small and concave to virtually absent; perianth unistratose to base. Perigynium $2 / 3$ of perianth length, strongly rhizogenous except for dorsal side, rhizoids originating from perigynium colorless. Androecia intercalary, with 3-4 pairs of bracts, 2-4-androus, stalk biseriate, $42.0-46.2 \mu \mathrm{m}$ long. Male bracts strongly inflated at base, widely obliquely ovate-triangular, 880-990 $\times 990-1210 \mu \mathrm{m}$. Elaters ca $105 \times 8 \mu \mathrm{m}$, bispiral, with or without homogenous endings (if present, up to $20 \mu \mathrm{m}$ long). Spores finely papillose, brown, $16.8-21.0 \mu \mathrm{m}$ in diameter.

HolotyPe. REUNION: E edge of Cirque de Mafate, on rocky N slope of Plateau de La Sale, along path, 26 Aug 1994, A. Vojtkó 9429 (NY 1717834).

The species is related to Solenostoma (Plectocolea) balfourii (Váňa) Váňa, Hentschel \& J. Heinrichs from which it differs by having $(i)$ a higher perigynium, ca $0.6-0.7$ of perianth length (vs. $0.3-0.5$ of perianth length in S. balfourii); (ii) obliquely to erect spreading rhizoids, mostly not fasciculate (vs. forming more or less clear fascicles); (iii) not rhizogenous leaves (vs. rhizogenous), and (iv) larger midleaf cells, up to $70 \times$ $57 \mu \mathrm{m}$ (vs. 28-35 $\mu \mathrm{m}$ ). The specimen was identified as Jungermannia borgenii Gott. ex Pears., from which it differs by having considerably more elongate and narrow cells in the perianth middle than in the midleaf (vs. similar in shape and size), 


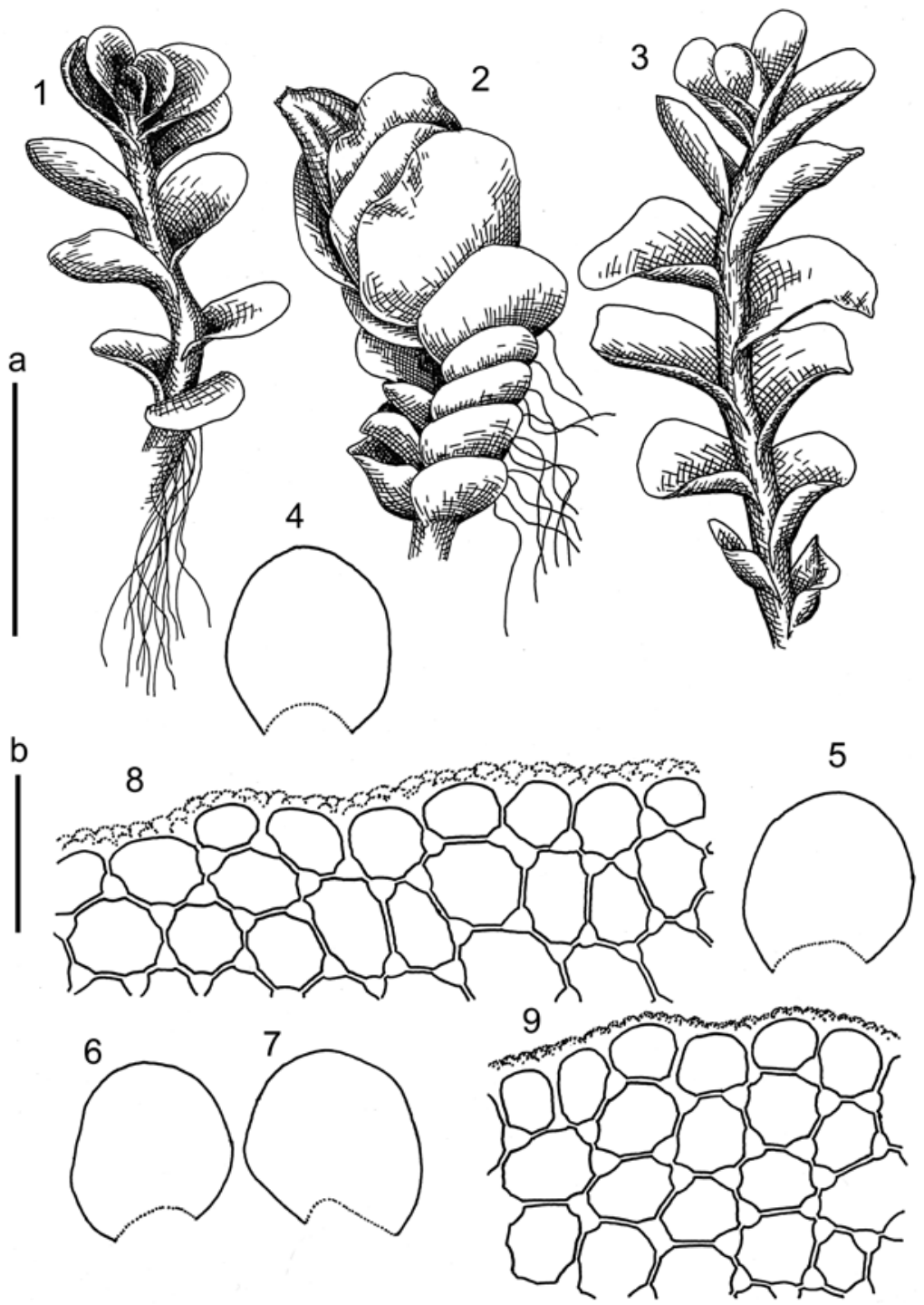

Fig. 2. Plectocolea subbalfourii Bakalin, sp. nov. 1 \& 3 - sterile plants; 2 - female plant; 4-7 - leaves; 8 \& 9- leaf margin cells. Scale bars: $\mathrm{a}-2 \mathrm{~mm}$ for $1-7 ; \mathrm{b}-50 \mu \mathrm{m}$ for $8 \& 9$. All from holotype (NY 1717834).

a high perigynium (vs. absent or vestigial), and larger leaf cells.

Acceptance of the generic name Plectocolea as different from Solenostoma is somewhat debatable. In most of the recent concepts the former name is commonly included to the latter as a synonym (Crandall-Stotler et al. 2009; Ván̆a et al. 2010, etc.), based on molecular evidence that some taxa commonly regarded as Plectocolea [e.g., P. hy- alina (Lyell) Mitt., P. subelliptica (Lindb. ex Kaal.) Evans] belong in genetic trees to the Solenostoma clade among other Solenostoma species. The latter was commonly interpreted as arguing for synonymization of the names. However, as shown by us earlier (Bakalin \& Vilnet 2012), there is a strongly separated clade including mostly East Asian taxa which could be called a separate genus. That is why Plectocolea was accepted here. 
3. Solenostoma rubrum var. underwoodii Bakalin, var. nov.

Fig. 3

The new variety differs from Solenostoma rubrum var. rubrum by having (i) purplish pale violet coloration (vs. commonly red coloration in var. rubrum); (ii) very small to virtually absent trigones inward from the leaf margin (vs. well developed); (iii) mostly subequally thickened leaf rim cells (vs. strongly unequally thickened, commonly with large trigones), and (iv) a long exerted perianth (up to $4 / 5$ or even more vs. shortly to $1 / 2-3 / 5$ of its length exerted).

Holotype. USA: Washington, King Co., Seattle, 12 Apr. 1891, C. V. Piper 21 (NY 564814).

IsotyPes. USA: WASHINGTON, King Co., Seattle, 12 Apr. 1891, C. V. Piper (NY 564815, 564817).

PARATYPe. USA: WAShington, Thurston Co., Olympia, 19 Apr. 1981 L. F. Henderson 2596 (NY 564816).
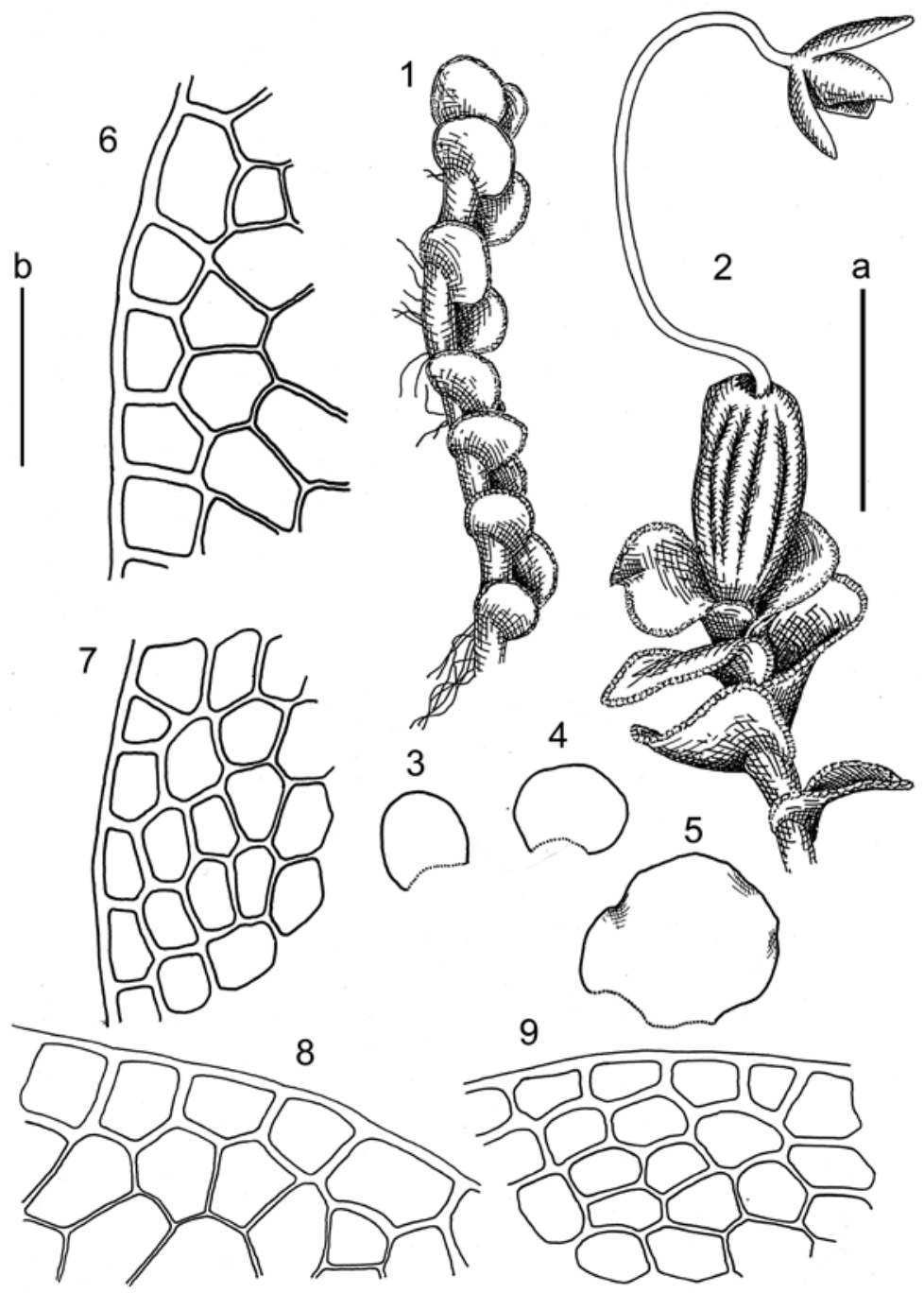

9

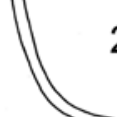

$2 \quad a$
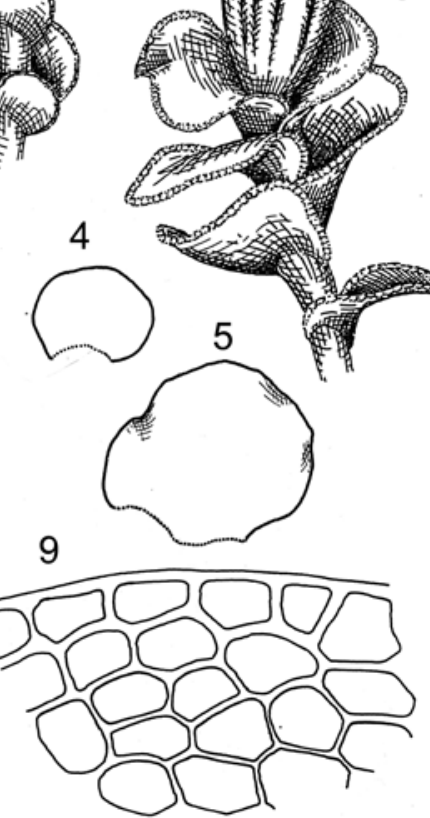

Fig. 3. Solenostoma rubrum var. underwoodii Bakalin, var. nov. 1 - sterile plants; 2 - female plant; 3-5 - leaves; 6-9 - leaf margin cells. Scale bars: $\mathrm{a}-1 \mathrm{~mm}$ for $1-5$; b - $50 \mu \mathrm{m}$ for $6-9$. All from holotype (NY 564814). 
The new variety is based on specimens identified as Nardia macounii by L. M. Underwood (NY), the taxon having never been validly described after it was published in Exsiccatae Hepaticae Americanae No. 169. The name was only mentioned by Váňa (1974: 400, translation from German by VB): 'no intraspecific taxa were described [within S. rubrum]; plants as Nardia macounii Underw. in sched. were selected, but put into ordinary modification (red colored)'. This conclusion was based on study of material in $\mathrm{F}$ (Váňa 1974: 398). My study does not support this concept. I think this taxon should be redescribed at least as a new variety, based on the aforementioned features. Perhaps the listed characteristics may refer var. underwoodii to Solenostoma gracillimum (Sm.) R. M. Schust. rather than S. rubrum (Gottsche ex Underw.) R. M. Schust. The new variety differs from $S$. gracillimum by $(i)$ the presence of trigones (although small) in the leaf (vs. almost uniformly absent); (ii) the smaller difference in size between rim and inner leaf cells, and (iii) its subequally thickened leaf margin (vs. equally thickened). In any case, the present taxon may occupy an intermediate position between the two species and requires further study.

\section{Plectocolea yunnanensis Bakalin, sp. nov.}

Fig. 4

Plants prostrate, pale greenish to greenish yellowish, 5-8 $\times 0.88-1.54 \mathrm{~mm}$, forming loose mats. Stem 264-374 $\mu \mathrm{m}$ in diameter, slightly flexuous, pale greenish, not branched (with the exception of rarely occurring ventral branches). Rhizoids common, colorless to grayish, brownish, purplish and purple (grayish are most common), originated mostly near ventral leaf base but not only there, spreading or loosely decurrent down the stem but not forming distinct fascicles. Leaves obliquely inserted, $c a 40-50^{\circ}$ with axis, dorsally decurrent for $c a 1 / 2$ of stem width, ventrally transversely inserted, not decurrent, laterally spreading, loosely sheathing the stem near base and recurved above, concave to concave-canaliculate, ovate to obliquely ovate, $880-1100 \times 924-1100 \mu \mathrm{m}$ (1:1), contiguous to (rarer) distant. Leaf cells in midleaf $35.7-63.0 \times 25.2-31.5 \mu \mathrm{m}$, oblong, walls obscurely thickened, sometimes flexuous, trigones moderate to small, concave, cuticle papillose; along margin 14.7-27.3 $\mu \mathrm{m}$, thin-walled, with thin to obscurely thickened external wall, cuticle smooth, trigones small, concave; lower part $37.8-67.2 \times 25.2-37.8 \mu \mathrm{m}$, walls obscurely thickened, flexuous, trigones moderate to small, concave to triangle, cuticle striolate. Dioicous. Perianth terminal, exerted for $c a 3 / 4$ of its length, pluriplicate, at mouth not or loosely turbinate, long conical; mouth crenulate due to protrudent, elliptic to clavate cells, with thin to obscurely thickened walls, cuticle smooth; cells in lower part of perianth 105-147 $\times 14.7-25.2 \mu \mathrm{m}$, thinwalled, trigones wanting; perianth bistratose in lower $1 / 3$. Perigynium $c a 1 / 5-1 / 4$ of perianth length. Female bracts sheathing perianth near base and obliquely spreading in upper half. Androecia intercalary or terminal (then branch dying above androecia), with 6-8 pairs of bracts, different generation divided by 1-2 pairs of sterile leaves, 2-3-androus, stalk 52.5-63.0 $\mu \mathrm{m}$ long, biseriate, body shortly elliptic, $168 \times 147 \mu \mathrm{m}$. Male bracts strongly inflated at the base and recurved in upper $1 / 3$. Elaters bispiral, $105-126 \times 8.4-10.5 \mu \mathrm{m}$, with homogenous ends $20-22 \mu \mathrm{m}$. Spores finely papillose, $10-12 \mu \mathrm{m}$ in diameter.

Holotype. CHINA: YunNan, Cangyuan Co., Banhong-Xiang, Nangunhe Nature Reserve, 17 Nov 2009, W. Ma 09-0698 (NY 1717750).

The taxon is closely related to at least three taxa: (1) Plectocolea boninensis (Horik.) S. Hatt., from which it differs by having commonly grayish to purplish rhizoids and papillose leaf cuticle (vs. brownish rhizoids and smooth cuticle); (2) Plectocolea granulata (Steph.) Bakalin, comb. nov. (BASIONYM: Nardia granulata Steph., Bull. Herb. Boissier 5: 100, 1897), from which it differs by having commonly grayish to purplish rhizoids originated mostly near the ventral leaf base, (vs. purple rhizoids originated along ventral side of stem); and (3) Plectocolea shinii (Amakawa) Bakalin, comb. nov. (BASIONYM: Jungermannia shinii Amakawa, J. Hattori Bot. Lab. 33: 156, 1970), from which it differs by having distinctly papillose cuticle 


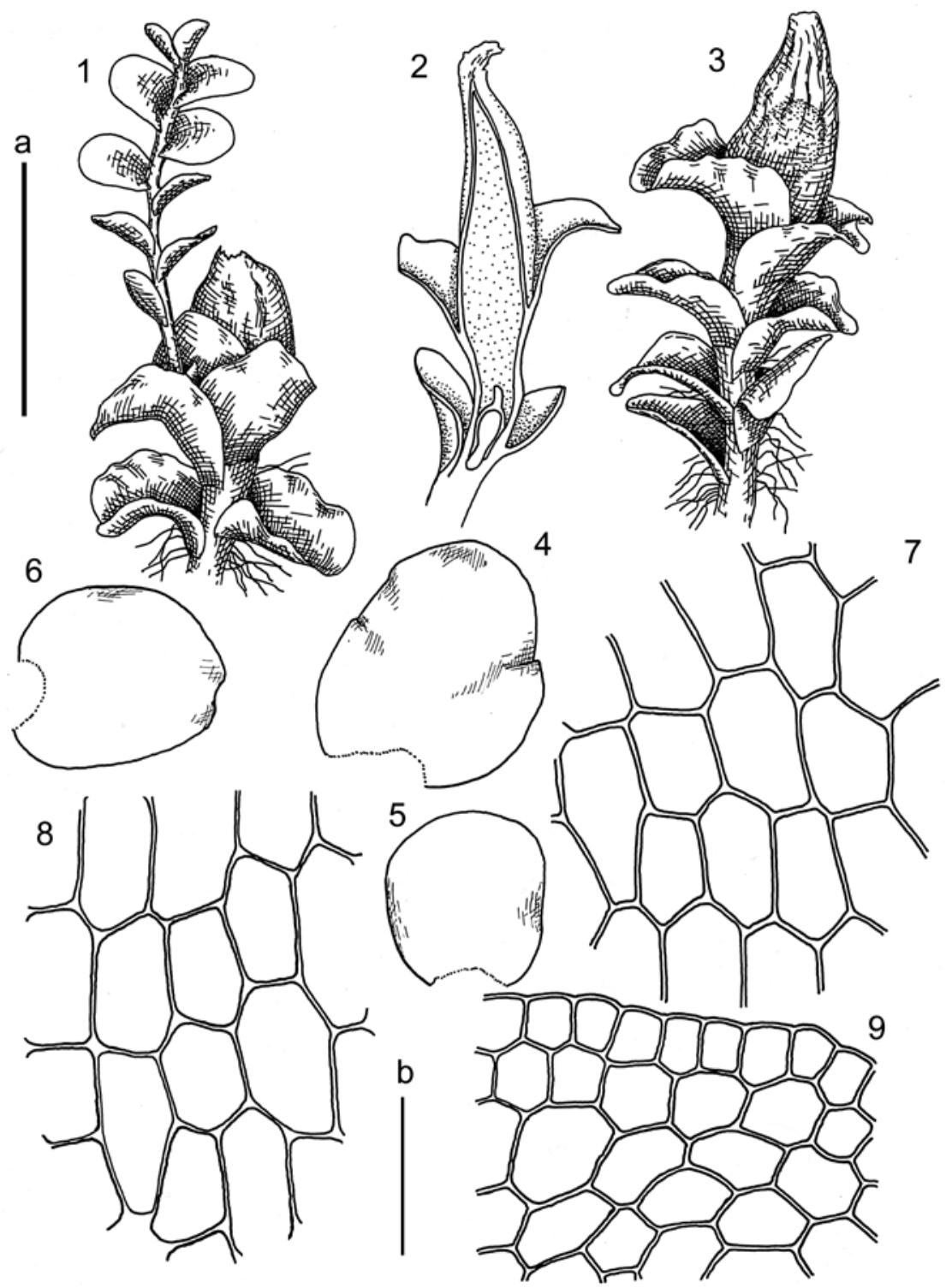

Fig. 4. Plectocolea yunnanense Bakalin, sp. nov. 1 \& 3 - female plants; 2 - perianth in longitudinal section; 4-6 - leaves; 7basal leaf cells; 8 - midleaf cells; 9 - leaf margin. Scale bars: a - $1 \mathrm{~mm}$ for $1-6 ; \mathrm{b}-50 \mu \mathrm{m}$ for $7-9$. All from holotype (NY 1717750).

(vs. mostly smooth cuticle, rarer faintly verrucose) and distinct trigones (vs. absent).

The three aforementioned species were synonymized with Plectocolea truncata (Nees) Herzog by Váňa and Inoue (1983) without giving detailed reasons (only the indication that the 'taxon' is 'ex- tremely variable', 1.c.: 134 is provided). I regard that solution as premature. Additional studies including molecular analyses are needed to resolve this question. Recent morphological and genetic studies on Plectocolea-Solenostoma in temperate East Asia showed the occurrence of a number of 
distinct species (Bakalin \& Vilnet 2009, 2012) formerly regarded as morphotypes of widely distributed taxa. I consider the treatment of the 'Jungermannia truncata complex' by Amakawa (1972) to be very reasonable. The described taxon differs from 'typical' Plectocolea truncata by having not thickened cell walls along the leaf margin (vs. thickened) and a long exerted perianth (vs. shortly exerted).

The taxon was identified as Jungermannia torticalyx Steph. by Li Wei and published in Bryophyta Selecta Exsiccatae (distributed by KUN, not by TNS), No. 61. From the latter it differs by its much smaller size, paler rhizoids, papillose cuticle and leaf shape.

\section{Solenostoma gracillimum subsp. camiguinense} Bakalin, subsp. nov.

Fig. 5

Plants ascending to creeping, brownish to yellowish brown, with red coloration in perianth, upper parts of female bracts and adjacent leaves, 5-8 $\times 2.2-3.3 \mathrm{~mm}$. Stem 418-506 $\mu \mathrm{m}$ in diameter (weak plants starting from $300 \mu \mathrm{m}$ in diameter), straight to slightly flexuous, not or sparsely branched. Rhizoids erect to obliquely spreading or decurrent down the stem but not forming fascicles, rather in loose mats or as plants attached to substrate, colorless to brownish. Leaves slightly laterally appressed to stem, rarer obliquely spreading, obliquely inserted (35-45 ${ }^{\circ}$ with axis), dorsally decurrent for $1 / 2-2 / 3$ of stem width, ventrally subtransversely inserted, not decurrent or decurrent up to $1 / 2$ of stem width, flattened to slightly concave, rarely sheathing stem near base and obliquely spreading above, orbicular to orbicular-widely ovate, $880-1320 \times 1166-1584 \mu \mathrm{m}(1.1-1.2: 1)$. Midleaf cells 35.7-42.0 × 31.5-37.8 $\mu \mathrm{m}$, thinwalled, trigones moderate to concave or slightly convex, cuticle loosely striolate; along margin $37.8-46.2 \mu \mathrm{m}$, very thick-walled but not equally thickened, tangentially (from margin to middle) elongated, cuticle striolate, next (inward) row of cells much smaller, 27.3-33.6 × 23.1-27.3 $\mu \mathrm{m}$, walls thickened, trigones moderate, concave; basal $48.3-77.7 \times 31.5-37.8 \mu \mathrm{m}$, thin- to slightly thick-walled, trigones moderate, slightly concave to slightly convex, cuticle loosely striolate. Dioicous(?). Perianth terminal, commonly red-purple to purple-brown and purplish brownish (on weak plants and unfertilized ones without reddish or purplish pigmentation), shortly fusiform to obpyriform or pyriform, distinctly 4-5-plicate, starting from lower $1 / 4$, exerted for $1 / 2-1 / 3$ of its length, gradually or suddenly contracted to the not or shortly beaked mouth; mouth crenulate to rather dentate, teeth 1-celled, composed of very thickwalled clavate to falcate or oblong cells, 52.5-73.5 $\times 18.9 \mu \mathrm{m}$, walls colorless, cuticle finely verrucose; cells in upper part of perianth 29.4-52.5 $\times$ 18.9-29.4 $\mu \mathrm{m}$, thin-walled, trigones moderate, triangle to concave, walls colorless to pinkish, cuticle smooth to obscurely papillose; cells in lower part of perianth $84-105 \times 29.4-37.8 \mu \mathrm{m}$, thin-walled, trigones moderate to small, concave, walls purplish to pink, cuticle smooth; perianth bistratose in lower $1 / 4$; cells of perianth folds strongly thickwalled. Perigynium virtually absent. Bracts similar to leaves, sheathing perianth.

Holotype. PHILIPPINES: Is. OF CAMIGUIN, from around fumaroles at base of New Volcano thrown up in 1871, s.d., Challenger Expedition s.n. (NY 1717840).

The new subspecies resembles $S$. gracillimum f. crenulatum, a taxon not known before from the Philippines, but differs by having concave to slightly convex trigones in the midleaf (vs. virtually absent), commonly a not beaked mouth (vs. uniformly beaked) and the perianth bistratose in the lower third (vs. unistratose to base). Taking into account these differences as well as the collecting site's extreme geographical isolation from the other localities of $S$. gracillima (generally an amphi-Atlantic taxon), I propose subspecific rank for the plants. Probably the taxon does not belong to $S$. gracillimum and may be regarded as a member of the Solenostoma koreanum-fusiforme group (Japan-Korean-Russian Far East endemics). The occurrence near fumaroles supports this suggestion. However, S. gracillimum subsp. camiguinense differs from the aforementioned group by having ( $i$ ) a not fusiform, 4-5-plicate perianth, suddenly contracted to the mouth; (ii) not equally thickened marginal cells (vs. commonly equally 


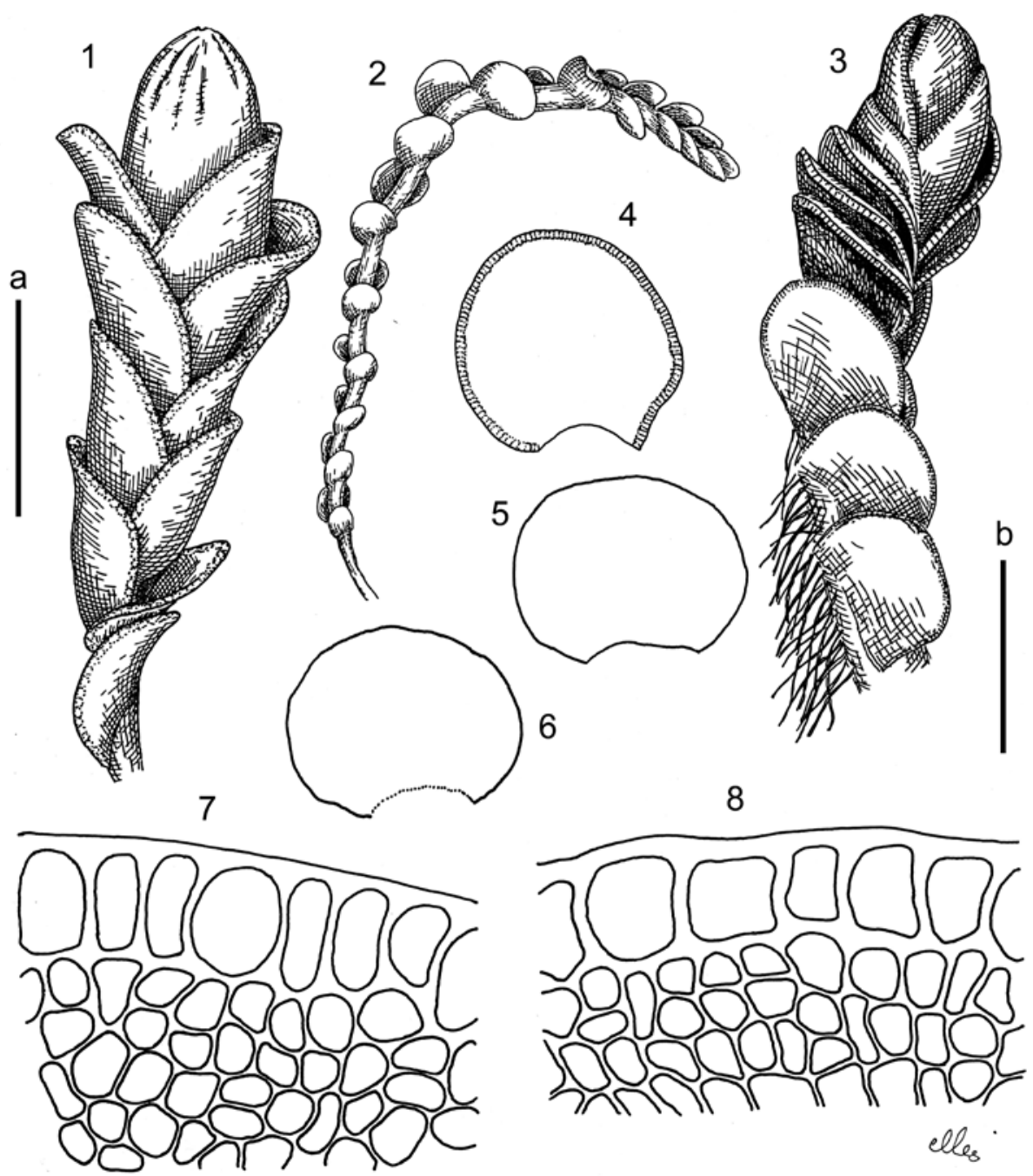

Fig. 5. Solenostoma gracillimum var. camiguinense Bakalin, subsp. nov. 1 - female plant; 2 - small-leaved branch; 3 - large sterile branch; 3-6 - leaves; $7 \& 8$ - cells along leaf margin. Scale bars: a $-2 \mathrm{~mm}$ for $1-6$; b - 50 $\mu \mathrm{m}$ for 7, 8 . All from holotype (NY 1717840).

thickened); (iii) larger plant size (wider than 2.2 $\mathrm{mm}$ vs. narrower than $2 \mathrm{~mm}$ ), and (iv) a perianth bistratose in its lower third. Future studies are needed to resolve this problem.

\section{Solenostoma inundatum var. grandirete} Bakalin, var. nov.

Fig. 6

Plants brownish to purple near apex, ascending to semierect, 4-7 $\times 0.66-1.10 \mathrm{~mm}$. Stem brownish, never purple, branching as subfloral innovations (mostly lateral, rarely ventral), 132-220 $\mu \mathrm{m}$ in diameter. Rhizoids colorless to brownish, spreading or decurrent down, but not forming fascicles. Leaves subtransversely inserted ( $\mathrm{ca} 70-80^{\circ}$ with axis), dorsally decurrent for $1 / 3-1 / 2$ of stem width, ventrally decurrent for $1 / 3$ of stem width, imbricate in upper part to distant, mostly concave, rarely flattened, bigger ones (near perianth) sometimes undulate, suborbicular to transversely 


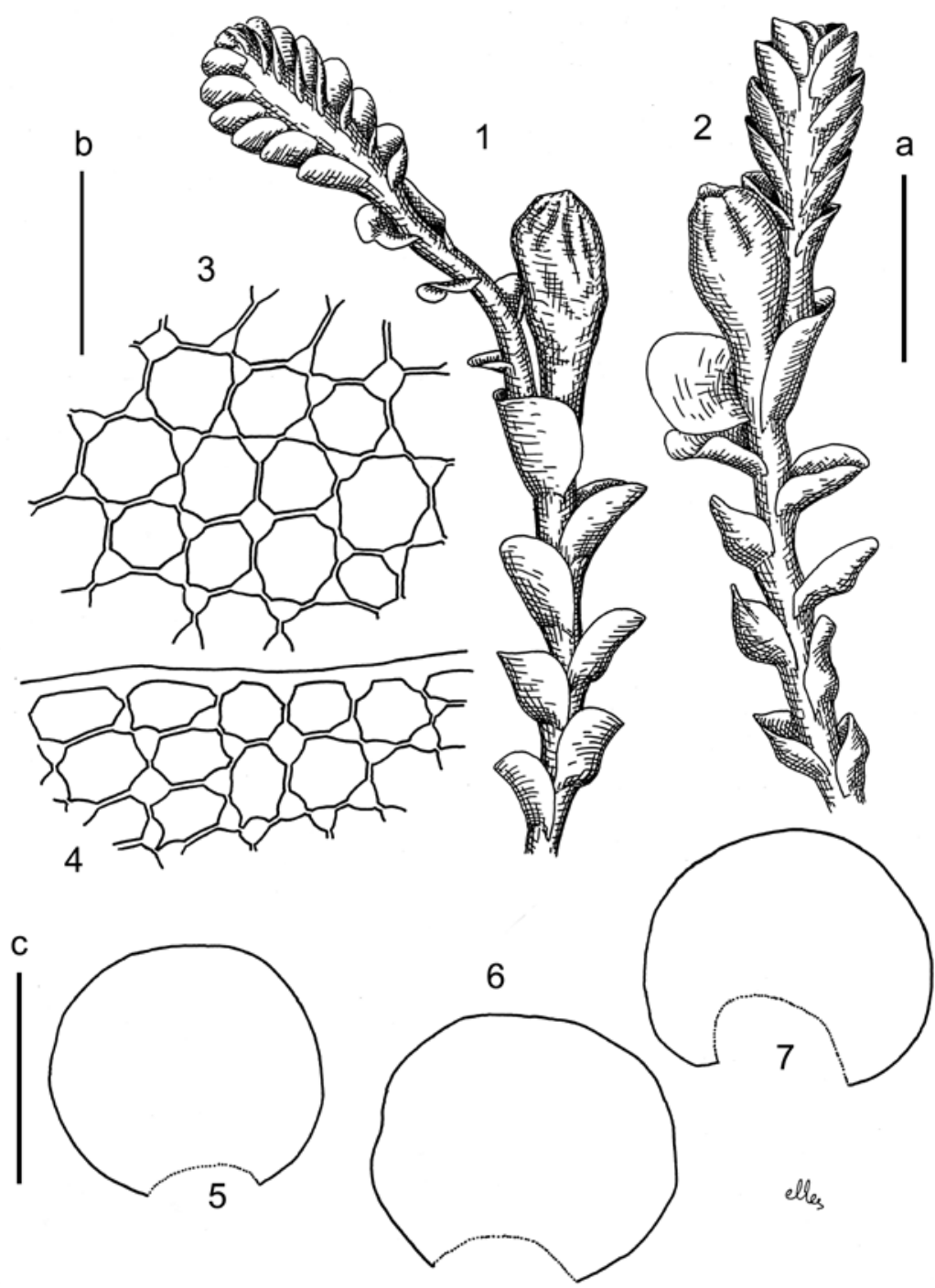

Fig. 6. Solenostoma inundatum var. grandirete Bakalin, var. nov. 1 \& 2 - fertile plants; 3 - midleaf cells; 4 - cells along leaf margin; 5-7 - leaves. Scale bars: $\mathrm{a}-1 \mathrm{~mm}$ for $1 \& 2$; b $-50 \mu \mathrm{m}$ for 3, 4; c $-500 \mu \mathrm{m}$ for 5-7. All from holotype (NY 1717891).

elliptic, 528-594 × 704-858 $\mu \mathrm{m}$ (ca 1.2-1.3:1). Leaf cells in midleaf subisodiametric, 21.0-31.5 $\times 21.0-31.5 \mu \mathrm{m}$, thin-walled, trigones moderate, convex, walls brownish, cuticle smooth; along margin 16.8-23.1 $\mu \mathrm{m}$, thin-walled with strongly thickened external wall, trigones large, convex, sometimes confluent, walls slightly brownish, with external commonly discolored; basal cells similar to those in midleaf but slightly larger, up to $30.7 \times 35.7 \mu \mathrm{m}$. Perianth terminal with $1(-2)$ sub- floral innovations, fusiform to (rarer) obpyriform, 3-4-plicate, with plicae commonly starting almost from base, rather gradually narrowed to narrow or very loosely beaked mouth, exerted for $1 / 2-2 / 3$ of its length; mouth crenulate due to protrudent oblong cells $23.1-44.1 \times 10.5-21.0 \mu \mathrm{m}$, external wall slightly thickened, other walls thin; cells in upper part of perianth 21.0-31.5 × 18.9-25.2 $\mu \mathrm{m}$, subisodiametric, trigones moderate, slightly convex, walls thin, colorless, cuticle smooth; 
cells in middle part of perianth shortly elongate 25.2-37.8 $\times 18.9-25.2 \mu \mathrm{m}$, walls thin, colorless, trigones small, concave; cells in lower part of perianth 42.0-65.1 × 18.9-23.1 $\mu \mathrm{m}$, thin-walled, concave, cuticle smooth, walls colorless; perianth bistratose in lower $1 / 3$. Perigynium virtually absent. Bracts similar to sterile leaves, sheathing perianth, commonly undulate at margin.

Holotype. NEW ZEALAND: GREAT BARRIER ISLAND, s.d. Hutton 3 (NY 1717891).

This plant, found among unnamed Jungermannia s.l. specimens, resembles Solenostoma inundatum (Hook.) Mitt. ex Steph. in habitat and appearance, but differs from it by having $(i)$ midleaf cells $21.0-31.5 \mu \mathrm{m}$ wide (vs. 20-22 $\mu \mathrm{m}$ wide); (ii) convex trigones in the midleaf (vs. straight-sided); and (iii) a strongly thickened and commonly discolored external wall of the leaf margin (vs. not or slightly thickened). The differentiating features may be regarded as induced by habitat conditions. The new variety may be confused with Solenostoma ruriflorum (Colenso) J. J. Engel, from which it differs by having (i) larger plant size, up to $1.1 \mathrm{~mm}$ wide (vs. up to $0.7 \mathrm{~mm}$ ); (ii) plants brownish with purple color near the apex only (vs. purple); (iii) mostly transversely elliptic leaves (vs. ovate to short-elliptic); (iv) thin-walled midleaf cells $21-31.5 \mu \mathrm{m}$ wide (vs. thick-walled and 17-20 $\mu \mathrm{m}$ wide); (v) smooth cuticle (vs. commonly papillose); and (vi) a perianth exerted for more than $1 / 2$ its length (vs. ca $1 / 2$ ).

\section{Notes on Plectocolea micrantha Mitt.}

The species was described by W. Mitten in Flora Vitiensis (1871) without indicating whether the taxon is dioicous or monoicous. Later, probably based on study of the same specimen ('Hawai, Hillebrand'), Stephani (1906) described the plant as being dioicous. He newly described the androecia (supposedly intercalary), but curiously cited the perianth description from Mitten (1871), with the note (Stephani 1906: 65) 'das Perianth des letzteren [Plectocolea micrantha] habe ich nicht gesehen'. Váňa (1975) again described this species as dioicous, and also noted the presence in the type material of androecia only, but no perianths. When I studied the holotype specimen I found the species to be paroicous. I found perianths (most of them young), antheridia and archegonia in the material. According to my observations the antheridia disappear very quickly after fertilization, and probably this is why Mitten (1871) did not describe them. I found juvenile archegonia above the androecia (which resembled being terminal). The description below is based on the holotype. My study indicates that the sexuality of the available collections of Plectocolea micrantha should be checked. Probably the name Plectocolea mauii (Aust.) Mill. should be used to name specimens now commonly kept under the epithet $P$. micrantha.

Plants creeping, flaccid pale greenish brownish to brownish with rusty tint, $8-12 \times 0.88-2.20 \mathrm{~mm}$. Stem 176-264 $\mu \mathrm{m}$ in diameter, not branched, pale brownish. Rhizoids common to numerous, erect spreading, colorless to purple, a tangle of differently colored rhizoids closely attaching the plants to the substrate. Leaves obliquely ovate, obliquely to subhorizontally inserted ( $\mathrm{ca} 10-30^{\circ}$ with axis) and oriented, dorsally decurrent for $c a 1 / 2-1 / 3$ of stem width, ventrally not decurrent, in upper part of shoot undulate at margin, 990-1276 × 1012-1298 $\mu \mathrm{m}(1: 1)$. Cells in midleaf 33.6-60.9 × 29.4-42.0 $\mu \mathrm{m}$, thin-walled, trigones small, concave, cuticle smooth; along margin 18.9-31.5 $\mu \mathrm{m}$, thin-walled with small concave trigones, cuticle smooth; leaf lower part 52.5-88.2 × 37.8-44.2 $\mu \mathrm{m}$, thin-walled, trigones small to moderate, concave (larger than in midleaf and along margin), cuticle smooth. $\mathrm{Pa}$ roicous. Perianth terminal, hidden within bracts or exerted for $1 / 4$ of its length, fusiform to conical, mostly pluriplicate, with 3-4 main plicae; mouth crenulate due to protrudent shortly oblong, $33.6-42.0 \times 21.0-25.2 \mu \mathrm{m}$, thin-walled cells; cells in middle part of perianth oblong, 44.1-63.0 $\times$ 21.0-25.2 $\mu \mathrm{m}$, thin-walled, trigones small to virtually absent; cells in lower part of perianth similar to those in middle; perianth unistratose to base. Perigynium $\mathrm{ca} 1 / 3$ of perianth length. Female bracts sheathing perianth near base and obliquely spreading in upper $1 / 3$. Androecia just below perianth (starting from female bracts), in 3-4 pairs (sometimes more), 1-3-androus, stalk biseriate, 


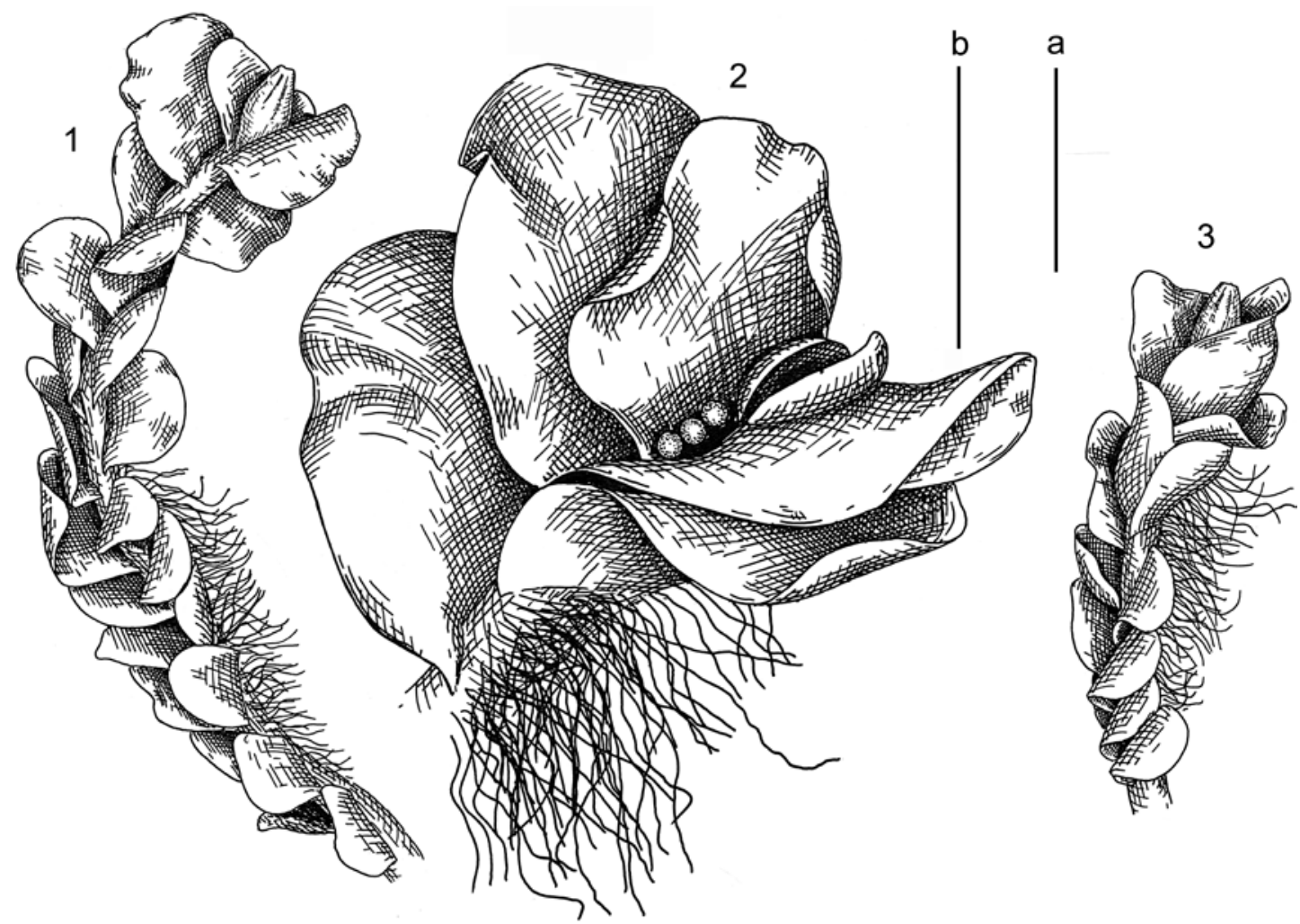

Fig. 7. Plectocolea micrantha Mitt. $1 \& 3$ - female plants; 2 - plants with antheridia and archegonia. Scale bars: a - 2 mm for $1 \& 3 ; \mathrm{b}-1 \mathrm{~mm}$ for 2 . All from holotype (NY 967546).

ca $31 \mu \mathrm{m}$ long, body shortly elliptic, $c a 105 \times$ $88.2 \mu \mathrm{m}$. Male bracts slightly inflated at base and obliquely spreading above (Fig. 7).

SPECIMEN EXAMINED: USA. HawaII, Sandwich Islands, s.d., W. B. Hillebrand s.n. (NY 967546, HOLOTYPE).

\section{Note on Jungermannia marcescens Mitt.}

Jungermannia marcescens (Fig. 8) was described by Mitten (1861: 91) as 'Caule erecto; foliis patentibus, verticulabus, medio excavates, orbiculatis, margine undulates; perianthio libero, oblong, obtuse, apice quinqueplicato; foliis involucralibus majoribus ad dimidium perianthii attingentibus' [translation by VB: 'Stem erect; leaves spreading, ventricose, concave, rounded, margin undulate; no perigynium, perianth oblong, obtuse, apex pentaplicate; bracts more than half of perianth length']. The species was described from Nepal (3700 m a.s.1.) based on J. D. Hooker's collections.

For a century the name Jungermannia marcescens was forgotten and did not appear in the literature. With the advent of intensive floristic studies of the Eastern Himalayas by Japanese botanists (e.g., Hara 1966) and an attempt to prepare (regrettably not completed) a Jungermannia s.l. treatment for Eastern Asia (e.g., Amakawa 1966, 1967), this species has been reintroduced to the botanical literature. Amakawa treated the taxon as a distinct species (1967: 264) and identified its sexuality as 'Dioicous? Male inflorescences unknown', but with a note that the 'upper leaves are often ventricose as if they contained antheridia'. Amakawa's viewpoint was not accepted by Ván̆a (1972), who 
synonymized the species with Solenostoma sanguinolenthum (Griff.) Steph. (J. sanguinolentha Griff. in 1.c.), based on the statement (1.c.: 68) that 'the type material of Jungermannia marcescens Mitt. is identical in all characteristics with the material of Jungermannia sanguinolentha Griff., only the plants are yellowish brown (there are also green colored plants of Jungermannia sanguinolentha Griff.), and the rhizoids are mostly scattered over the stem and rarely forming the fascicle along the stem'. The latter view on synonymy was repeated 37 years later by Váňa and Long (2009). During my study of Mitten's isotypes of $J$. marcescens and $J$. sanguinolentha in NY (concerning lectotypification see Váňa 1972) I found that the plants described as J. marcescens differ from $S$. sanguinolenthum in the following aspects:

1. The type material of $J$. marcescens is paroicous, not dioicous as in $S$. sanguinolenthum. Antheridia below the perianth are often lacking in this species, however, and are present in approximately each third shoot. This situation is rather common in the paroicous species of Solenostoma where antheridia are easily washed away when herbarium material is wetted. The paroicous state also suggested by the constant fertilization of the archegonia in the absence of antheridial shoots. This observation prompted a careful search for antheridia in the recently described species $S$. pseudopyriflorum (Bakalin \& Vilnet 2009), which has been commonly confused with the geographically vicarious, dioicous $S$. pyriflorum Steph. Thus, Amakawa's statement (1966: 264) 'often ventricose as if they contained antheridia' is a result of the presence of antheridia in reality.

2 . The perianth in $J$. marcescens is bistratose in the lower $2 / 3$ of its length, and in $S$. sanguinolentum only in the lower third.

3 . The perianth of $S$. sanguinolentum is much larger than in J. marcescens (to $6 \mathrm{~mm}$ long vs. to $1.5 \mathrm{~mm}$ long).

4. The typical coloration of $J$. marcescens plants is yellowish brownish to brown, as was noted by Mitten (1861) and Amakawa (1966) and observed in my study. In contrast, the typical coloration of S. sanguinolenthum is light to deep pink. As noted by Ván̆a (1972), green-colored plants of S. san- guinolenthum may occur, but the green coloration can be treated as merely the absence of secondary pigmentation. The presence of brown pigmentation versus pink in the well-exposed phases is quite another matter. Correlated with this feature is rhizoid coloration; it is colorless to pinkish in S. sanguinolenthum versus brown to golden brown or red-brownish in $J$. marcescens.

5. J. marcescens has rather pachydermous leaf cells, versus leptodermous in S. sanguinolenthum; this character correlates with the former's more rigid plant habit than the latter. In a relative sense, $J$. marcescens resembles species of the S. pyriflorum group, whereas $S$. sanguinolenthum is similar to those of the $S$. fusiforme group.

In view of these observations I suggest that $J$. marcescens is a 'good' taxon which is rather distant from $S$. sanguinolenthum and merits species rank. Therefore a new combination is proposed: Solenostoma marcescens (Mitt.) Bakalin comb. nov. (BASIONYM: Jungermannia marcescens Mitt., Journ. Proc. Linn. Soc. London 5: 91. 1861). Below I provide a morphological description of $S$. marcescens based on study of type material in NY.

Plants erect to ascending, brownish to yellowish and pale brown-golden, 1.0-1.3 mm wide, 5-8 mm long, sparsely laterally branched. Stem elliptic in cross section, ca $0.15-0.20 \times$ $0.28-0.35 \mathrm{~mm}$, with cortex obscurely developed, cells in 2-3 layers along margin $c a$ 15-23 $\mu \mathrm{m}$ in diameter (in cross-sectional view) moderately thick-walled, with small concave trigones, inner cells larger, mostly 5-6-gonal, ca 22-34 $\mu \mathrm{m}$ in diameter, thin-walled, with small concave trigones. Rhizoids very dense, rigid, mostly brown to golden brown and red-brownish, erect from the stem in dense mat, or decurrent down (in upper part of shoot) and forming fascicles. Leaves contiguous to imbricate, sheathing stem at base, when flattened transversely elliptic to reniform, rarely retuse at apex; transversely inserted and oriented, $0.7-1.2 \times 1.2-1.8 \mathrm{~mm}(1: 0.6-0.7)$, shortly (less than $1 / 5$ of stem width) or barely decurrent in dorsal side; margin entire and flat, rarely undulate and loosely crispate. Midleaf cells mostly oblong hexagonal, $33-50 \times 22-31 \mu \mathrm{m}$, thin-walled, with 


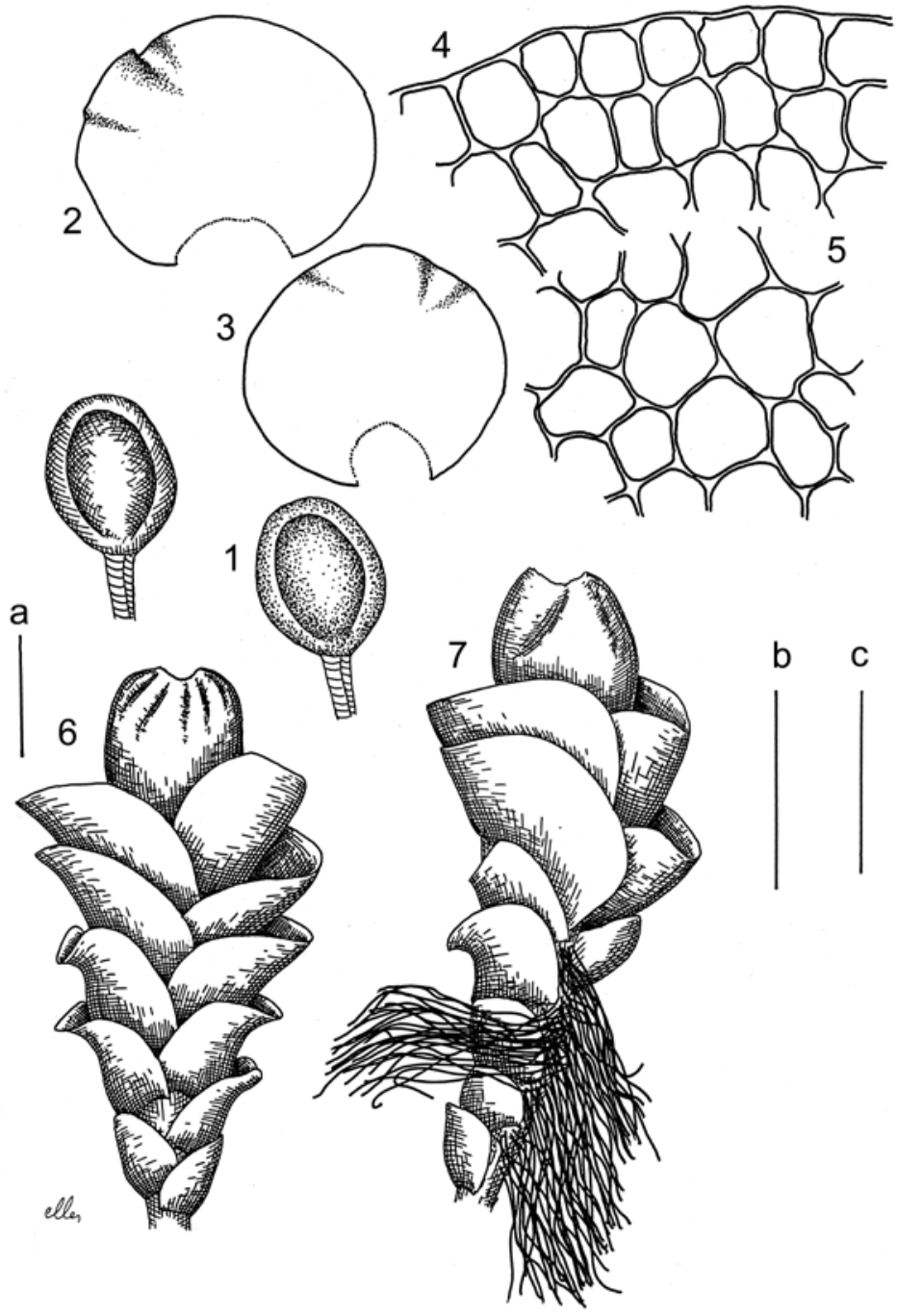

Fig. 8. Solenostoma marcescens (Mitt.) Bakalin. 1 - antheridium; 2 \& 3 - male bracts; 4 - leaf margin cells; 5 - midleaf cells; $6 \& 7$ - perianthous plants. Scale bars: $\mathrm{a}-100 \mu \mathrm{m}$ for $1 ; \mathrm{b}-1 \mathrm{~mm}$ for $2,3,6,7$; $\mathrm{c}-50 \mu \mathrm{m}$ for 4 , 5. All from isolectotype (NY 00961609).

small concave trigones, walls yellowish (probably due to age); along margin 14-28 $\mu \mathrm{m}$, mostly thinwalled, sometimes with thickened external wall, trigones moderate, triangle, near base $42-73 \times$ 25-36 $\mu \mathrm{m}$, oblong hexagonal, thin-walled, with small concave trigones. Perianth terminal, without subfloral innovations, red-brown in color, tubular to subclavate, loosely or evidently 3(-5)-plicate in upper $1 / 4$, gradually narrowed to indistinctly beaked mouth, $1.2-1.5 \times 0.9-1.0 \mathrm{~mm}$, exerted for $2 / 5-1 / 2$ of its length; mouth crenulate due to protrudent subclavate elongated thin-walled to slightly thick-walled cells, ca $28 \times 16 \mu \mathrm{m}$; cells in middle part of perianth mostly 5-6-gonal, oblong, thin-walled, walls brown, with large, slightly convex trigones, $36-45 \times 28-34 \mu \mathrm{m}$; cells near perianth base elongate with walls brownish, thin, trigones small and concave, 42-84 × 16-19 $\mu \mathrm{m}$, cuticle smooth to loosely striolate; perianth bistratose in lower $1 / 2-3 / 5$ of its length; rhizogenous 
in lower half. Bracts sheathing perianth, similar in size with larger leaves. Perigynium vestigial. Androecia intercalary, divided from perianth by 2-3 pairs of sterile leaves, with 2-3(-5) pairs of bracts, 1-2-androus, stalk biseriate, 75-100 $\mu \mathrm{m}$ long, body nearly spherical, $c a 130-140 \mu \mathrm{m}$ in diameter, with reddish tint, bracts similar to larger leaves but inflated at base.

SPECIMEN EXAMINED. NEPAL: Yangura Valley J.D. Hooker No. 1316 (ISOLECTOTYPE, cf. Váňa 1972, NY 961508).

For comparison with the afore-described species I provide a description of Solenostoma sanguinolentum (Griff.) Steph., based on type material in NY.

Plants erect to prostrate, flaccid, with sheathing leaves (similar to those in J. eucordifolia Schljakov), brown-red to purple brown and purplish, 10-20 $\times$ (1.32-)1.76-2.64 mm. Stem rarely branched (laterally intercalary), reddish brown, 264-308 $\mu \mathrm{m}$ in diameter. Rhizoids numerous in brownish fascicles decurrent down the stem; sometimes fascicles not well developed and rhizoids few. Leaves subtransversely inserted, canaliculate to canaliculate-concave, decurrent dorsally for (1.0-) 1.5-2.0 of stem width, ventrally arcuate inserted, decurrent for $1.0-1.2$ of stem width, obliquely widely ovate, sometimes (bigger ones) crispate at margin, $1.28-1.32 \times 1.54-1.65 \mathrm{~mm}(1.1-1.15: 1)$, not or very loosely rhizogenous. Leaf cells in middle shortly oblong, 37.8-48.3 × 25.2-37.8 $\mu \mathrm{m}$, thin-walled, trigones moderate, concave, walls colorless to pinkish, cuticle smooth; along margin 25.2-42.0 $\mu \mathrm{m}$, thin-walled (with thin external wall), trigones moderate, concave, walls colorless to pinkish, cuticle smooth; leaf basal part cells $63-84 \times 31.5-$ $48.3 \mu \mathrm{m}$, walls pinkish, thin to slightly thickened, trigones moderate, concave, cuticle obscurely papillose. Dioicous (?, only female organs seen). Perianth terminal, rhomboidal to clavate, $c a 5.94 \times$ $1.76 \mathrm{~mm}$, irregularly plicate (mostly with 5 plicae) in upper $1 / 5$, gradually or suddenly contracted to the not-beaked mouth (beak not well developed in unfertilized perianths), exerted for $3 / 4-4 / 5$ of its length; cells in upper part of perianth subisodiametric (mostly wider than long), 39.9-46.2 ×
24.0-56.7 $\mu \mathrm{m}$, cuticle smooth, trigones moderate, concave, walls thin, pinkish; cells in middle part of perianth $46.2-67.2 \times 42-63 \mu \mathrm{m}$, thin-walled, trigones moderate, concave to slightly convex, walls pinkish, cuticle smooth; cells in lower part of perianth $105-189 \times 21.0-35.7 \mu \mathrm{m}$, oblong, thin-walled, walls pinkish; perianth bistratose in lower third. Perigynium virtually absent. Bracts loosely sheathing perianth, at margin undulate to crispate.

SPECIMENS EXAMINED. INDIA: Khasia, W. Griffith 1 (ISOLECTOTYPE, cf. Váňa 1972, NY 967468); upper Assam, W. Griffith s.n. (NY 67469).

ACKNOWLEDGEMENTS. I am much indebted to Dr. Barbara Thiers and Ms. Gena Fernandez for help during the work in NY, to Mr. Matvei Bakalin for providing the line drawings, and to the anonymous reviewer for helpful comments on the manuscript. The study was supported in part by the Russian Foundation for Basic Research (grants nos 12-04-91150, 13-04-00775).

\section{REFERENCES}

Amakawa T. 1966. New or little known Asiatic Species of the family Jungermanniaceae II. J. Hattori Bot. Lab. 29: 253-266.

Amakawa T. 1967. New or little known Asiatic Species of the family Jungermanniaceae III. J. Hattori Bot. Lab. 30: 181-198.

AMAKAWA T. 1972. New or little known Asiatic species of the family Jungermanniaceae, VII. J. Hattori Bot. Lab. 35: $382-390$.

Bakalin V. A. \& Vilnet A. A. 2009. Two new species of Jungermanniaceae from Asiatic Russia. Arctoa 18: $151-162$.

BAKAlin V. A. \& Vilnet A. A. 2012. New combinations and new species of Solenostoma and Plectocolea (Solenostomataceae) from the Russian Far East. Bryologist. 115(4): 566-584.

Crandall-Stotler B., Stotler R. E. \& Long D. G. 2009. Phylogeny and classification of the Marchantiophyta. Edinburgh J. Bot.. 66: 155-198.

HARA H. 1966. The flora of the Eastern Himalaya. University of Tokyo, Tokyo.

MitTEN W. 1861: Hepaticae Indiae Orientalis: an Enumeration of the Hepaticae of the East Indies. J. Proc. Linn. Soc., Bot. 5: $89-128$.

MitTen W. 1871. Ordo CIX. Jungermanniales. In: B. SEEMAN, Flora Vitiensis. 2: 404-418. Lovell Reeve and Co., London. 
STEPHANI F. 1906. Species Hepaticarum. 2. Acrogynae. Maison a Lyon, Geneve \& Bale.

VÁŇA J. 1972. Miscellaneous notes on the Asiatic Jungermannioideae II. J. Hattori Bot. Lab. 36: 57-74.

VÁŇA J. 1974. Studien über die Jungermannioideae (Hepaticae) 6. Jungermannia Subg. Solenostoma: Europäische und nordamerikanische Arten. Folia Geobot. Phytotax. 9: $369-423$.

VÁŇA J. 1975. Studien über die Jungermannioideae (Hepaticae) 9. Jungermannia subg. Plectocolea und subg. Solenostoma in Hawaii; Erganzungen und Synopsis der Gattung Jungermannia. Folia Geobot. Phytotax. 10: 357-382.

VÁŇA J. \& InOUE H. 1983. Studies on Taiwan Hepaticae V. Jungermanniaceae. Bull. Natl. Sci. Mus., Tokyo, B 9(4): 125-142.

VÁŇA J. \& LONG D. G. 2009. Jungermanniaceae of the SinoHimalayan region. Nova Hedwigia. 89: 485-517.

VÁŇA J., HENTSCHEL J. \& HEINRICHS J. 2010. New combinations in Jungermanniales: transfer of 32 taxa to Solenostoma Mitt. Cryptog. Bryol. 31: 135-139.

Received 4 March 2013 